\title{
The rocky road to justice for atrocities committed during the Kosovo war
}

The Kosovo war marked a period of unimaginable violence. The Serbian campaign of ethnic cleansing of Kosovar Albanians, overseen by then-president of Serbia, Slobodan Miloševic, met with retaliatory atrocities by opposing forces, led by the Kosovo Liberation Army (KLA). In the years since, various have been created to deliver justice, but they have been hampered by continued distrust intimidation of witnesses, and perceptions of unfairness from opposing sides. At Vrije Universiteit Brussel, Dr Mathias Holvoet has closely examined the post-conflict justice responses related to the Kosovo war with the aim of identifying a more comprehensive and meaningful road to justice, whic does not complicate but could eventually nurture reconciliation.

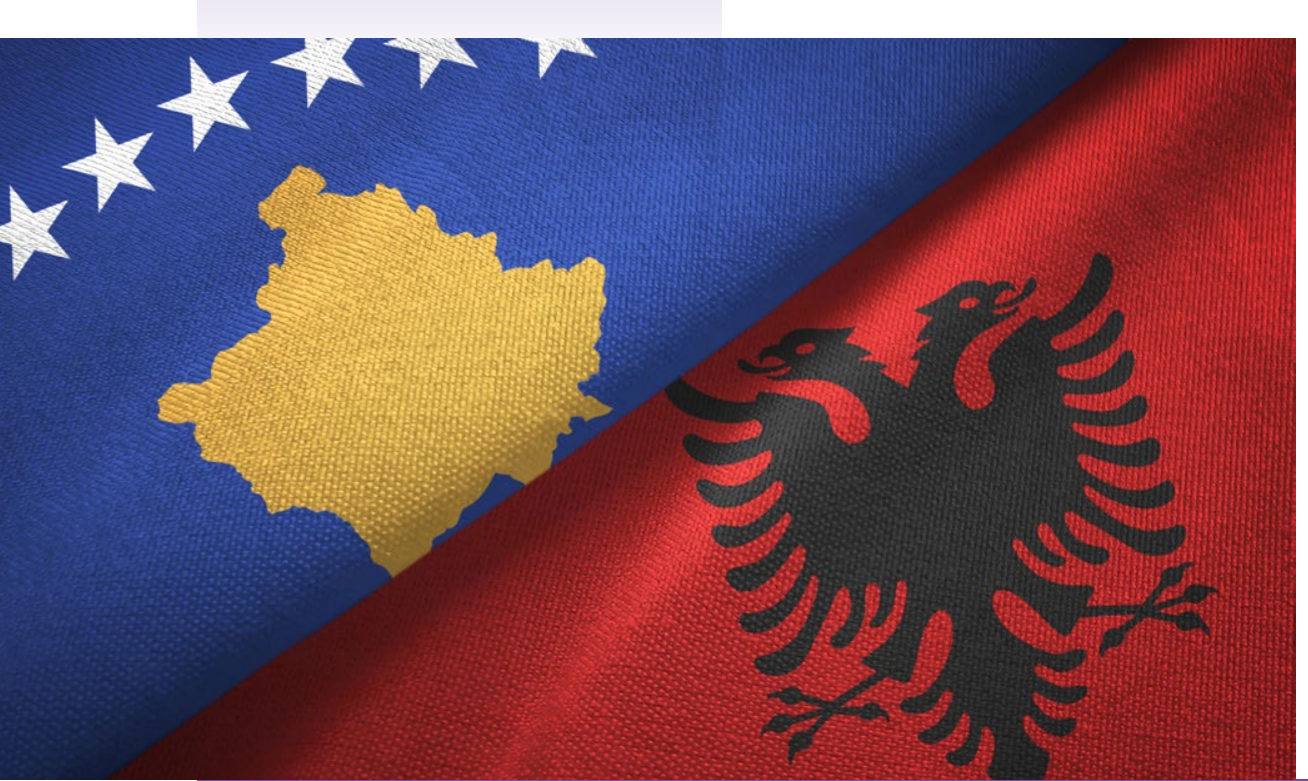

including summary executions of ethnic Serbs, ethnic Albanian 'traitors', and other minorities. Fewer people still know about the efforts to deliver justice and of the wa. mes perpetrated for reasons of ethn In 1998, years of smountering tensions surrounding the breakup of Yugsostavia - 10 voet, a researcher wi Dractical experience in the field of ethnic Albanians against ethnic Serbs, and resulting in atrocities that continue to haunt the region today.

For the broader public, the Kosovo war seems inextricably linked with the North Atlantic Treaty Organization (NATO) intervention in 1999, which halted the Serbian campaign of ethnic cleansing of Kosovar Albanians in Kosovo, oversee by the then-president of Serbia, Slobodan Milošević. Ethnic Albanian citizens were subjected to killings, sexual vilence, and the destruction of social, cultural, and personal property. Less

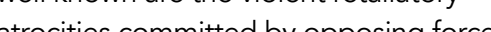
(a) International Criminal Law, believes that the approach to accountability for war has been inconsiderate and incomprehensive. The competence to deliver accountability has been scattered in a piecemeal fashion across various institutions who either lacked the time, the capacity, and/or the appropriate jurisdictional mandate to dispense meaningful, inclusive, and comprehensive criminal justice.

From his base at Vrije Universiteit Brussel, where he is affiliated with the and the Fund omentights Research Centre (FRC). Dr Holvoet is putting his considerable experience into examining the different mechanisms used to deal with the investigation, prosecution, and adjudication of atrocity crimes during the Kosovo war - and most importantly to illuminating possible ways forward.

A FAILED SEARCH FOR JUSTICE The jurisdiction of the first institution to handle crimes committed during the Kosovo war, the International Crimina Tribunal for the Former Yugoslavia (ICTY), was strictly confined to crimes Crimes colluning he aned conflict. Crimes committed in the aftermath of the Moreover, the ICTY was curtailed by the
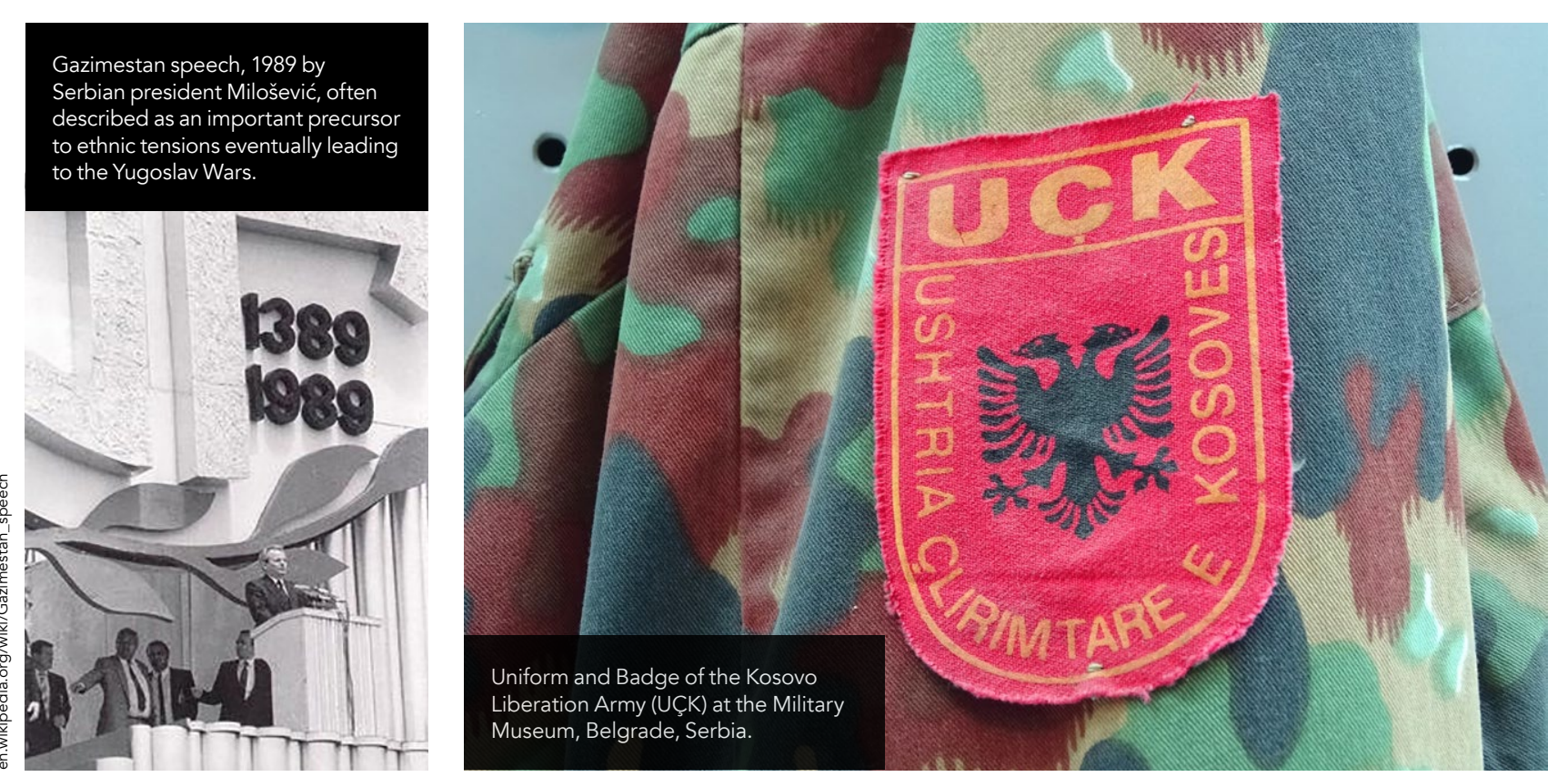

adoption of the Completion Strategy practice prohibited the ICTY Office in the Prosecutor from issuing any further dictments ffer 2004 . Most significa this deadline was a severe blow for investigations into sexual crimes. Just

establishing a wholly new institution, the Kosovo Specialist Prosecutor's Office (KSC \& SPO). However, the KSC \& SPO's legitimacy has been extremely fragile from the outset, as its mandate has been effectively restricted

of whom feel that they are unequally comes to criminal justice for when it committed during the Kosovo war, with the general consensus being that crimes committed by Serbs "enjoy widespread impunity". For Kosovar Albanians, the six former senior Accountability for crimes committed has glorified the memberwere during the Kosovo war has been whose crimes often ultimately convicted ind had overt and by the ICTY, a inconsiderate and incomprehensive. underwhelming track record. Most frustratingly to many observers, and particularly to ethnic Albanians, was the ware his

to investigating, prosecuting, and tacit support of
international bodies trial could be completed.

Alongside the ICTY, local war crime trials were held under the auspices Kosovo (UNMIK) and, subsequently, the European Union Rule of Law Mission (EULEX). While these trials met with some success in holding accountable lower-level perpetrators, they failed to successfully prosecute high-level actors responsible for crimes committed during the Kosovo war, with witness intimidatio being the main detrimental factor.

Acknowledging that EULEX would not be able to prosecute high-profile accused and would not be able to guarantee the protection of witnesses and judges, in 2015 the EU and the USA
pressured the Kosovo Assembly into adjudicating crimes by former KLA

such as NATO and the United Nations (UN), which raises the question as to whether political responsibility can negate individual criminal responsibility. fuelled by the comp pete is filliner $\begin{array}{ll}\text { This has led to widespread frustration } & \text { fuelled by the complete unwillingness of } \\ \text { among Kosovar Albanians, many } & \text { Serbia to assume any public or collective }\end{array}$ among Kosovar Albanians, many

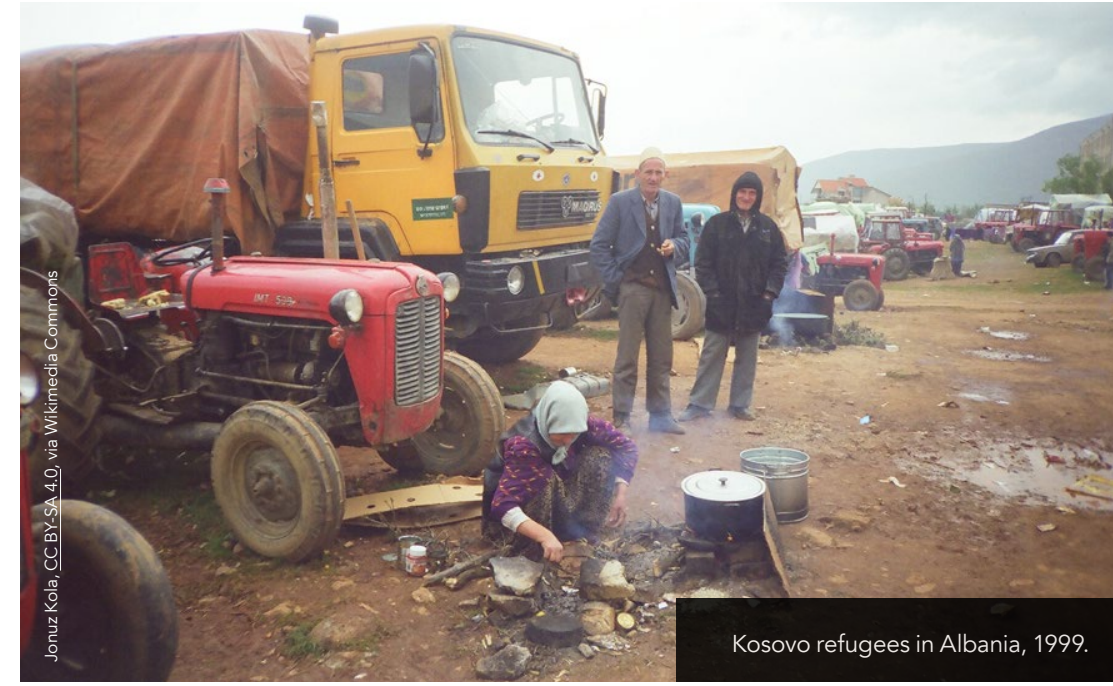




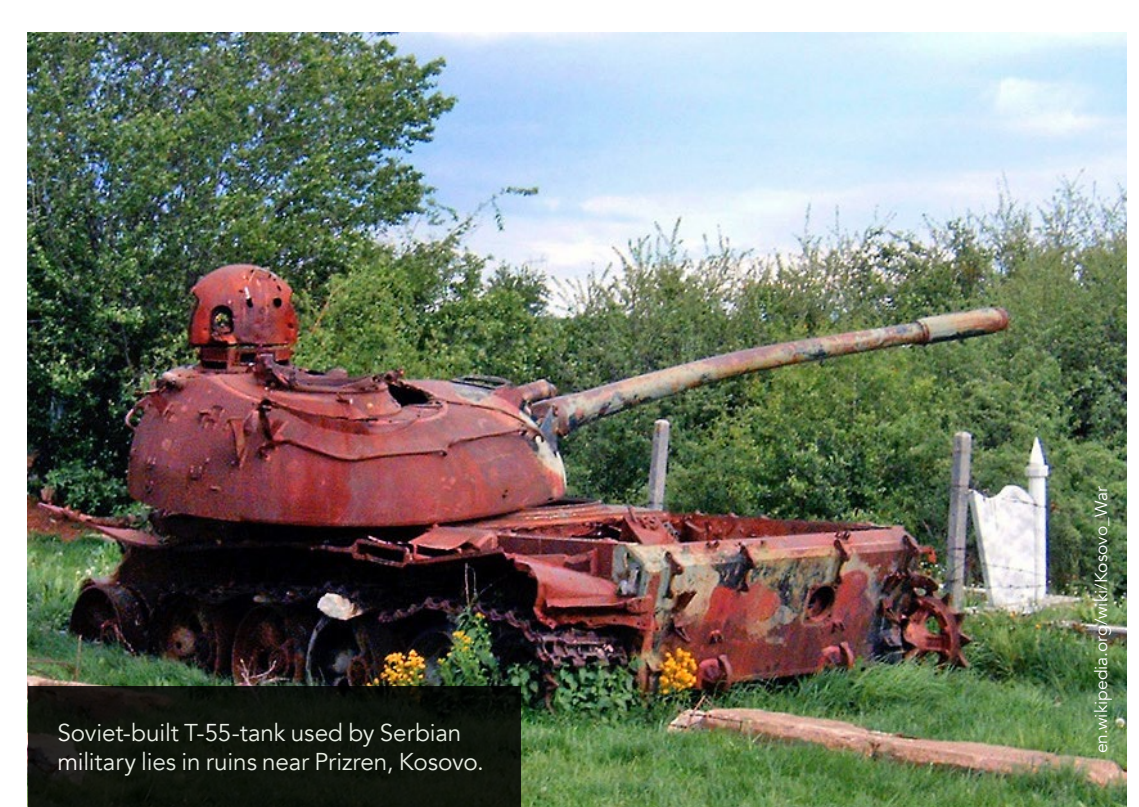

responsibility for its numerous crimes population: the denial of the 1999 Recak massacre by the incumbent Serbian president Aleksandar Vučč́ in which 45 Albanian civilians lost their lives, being a notable and recent example.

Ultimately, instead of facilitating recognition of responsibility for atrocities on all sides, the mandates and performances of the different accountability mechanisms have led to either the denial or minimisation of responsibility. Moreover, these efforts to deliver criminal justice for atrocities committed during the Kosovo war have further fuelled grievances between $S$ e dnd Kosovar Albanians, in a way that

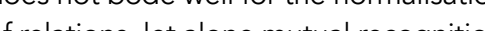
between Serbia and Kosovo.

\section{TOWARDS TRUTH}

RECONCILIATION, AND JUSTICE

Dr Holvoet suggests that a new

pproach is needed to address postconflict resolution in the region. In particular, the EU and USA, as Kosovo and Serbia's main partners, should adopt a principled approach that includes accountability as one of the main pillars of dialogue. Ideally, this would lead to mutual recognition and membership

A principled approach implies that al crimes committed deserve justice on

Serbia and Kosovo being incentivised accountability for atrocities committed and this regard, a more Serbia is warranted, as the country has to commit and engage in delivering

acceptance of responsibility for crimes conmited, and for the justice process, community, and perhaps from the wider international community who threw their support behind the KLA.

However, it is increasingly acknowledged the path out of conflict is not paved by justice, but by non-judicial transitional justice approaches, such as truth and reconciliation commissions and apologies. The first to tread such a road was post-Apartheid South Africa, but more recent commissions include those in post-Pinochet Chile, post-communist East Germany, post-colonial Canada and Australia, and post-Maoist conflict Nepal. While these commissions have met with differing levels of success, they contheless mark a sea change in the mane and diague of post-con tict Serbia, the EU and USA could certaily promote a more holistic approach to societal reconstruction, which, besides truth and reconciliation commissions

\section{A principled approach implies that} all crimes committed deserve justice on an equal footing.

been dragging its feet with regards to and apologies, could include additiona prosecutions, particularly of high-level pathways such as support for the former officials, and continues to be development of free and independent in a state of denial. If Serbia were to continue along this path, one option KSC \& to expand the mandate of the by the Serbian side. Similarly,

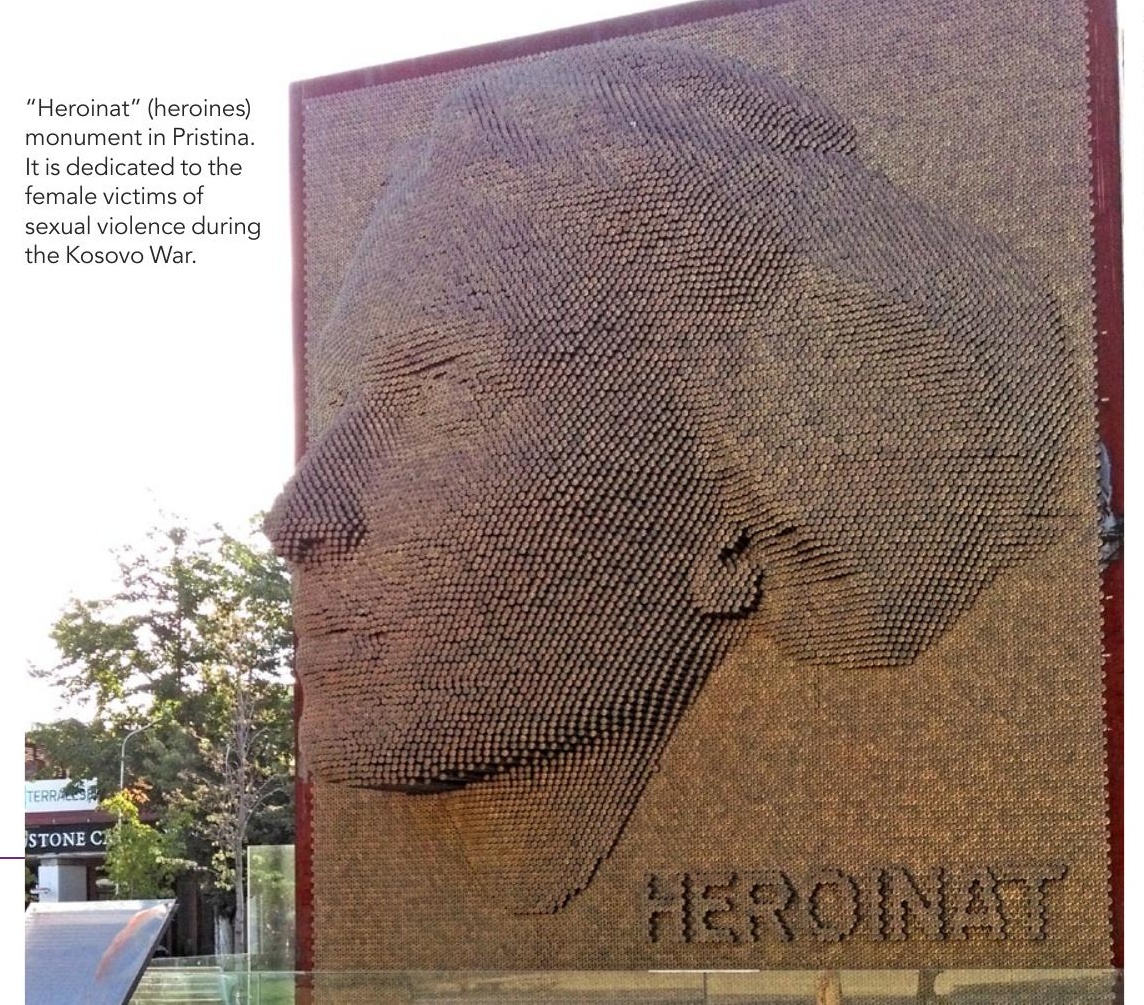

\section{Behind the Research}

\section{Dr Mathias Holvoet}

E: Mathias.Holvoet@vub.be T: $+32485440464 \quad$ W: https:///brussels-school.be/team/mathias-holvoet
https://www.linkedin.com/in/mathias-holvoet-45588b2b/ O Mathias Holvoet @MathiasHolvoet

Research Objectives

Dr Holvoet examines the work of the different mechanisms Dhat are dealing with the winestigation, prosecution and

\section{Detail}

Bio

Mathias Holvoet holds a PhD (2018) in International Crimina Law from the Vrije Universteit Brussel, whe he is affilited as a researcher with the Brussels School of Governance (BSoG) and the Fundamental Rights Research Centre (FRC). Dr Holvoet has over ten years of academic and practical experience in the field of International Criminal Law.

\section{References}

Holvoet, M. (2021). Frustrated Justice: Revisiting the ICTY's Involvement in Adjudicating Crimes Committed during the Kosovo War. In. Hehir, A. and Sheremeti, F. (eds). Kosovo and Transitional Justice. The Pursuit of Justice After Large Scale
Conflict. Routledge, ISBN 9780367529017.

Holvoet, M. (2020). Introducing the Special Issue 'Critical Perspectives on the Law and Politics of the Kosovo Specialist Chambers and the Specialist Prosecutor's Office'. International view, 20(1), 1-15. Available a

作/10.1163/15718123-02001012

Holvoet, M. (2016). The Continuing Relevance of the Hybrid or Internationalized Justice Model: The Example of the Kosovo Specialist Chambers. Criminal Law Forum, 28, 35-73. Available at: https://doi.org/10.1007/s10609-016-9296-1

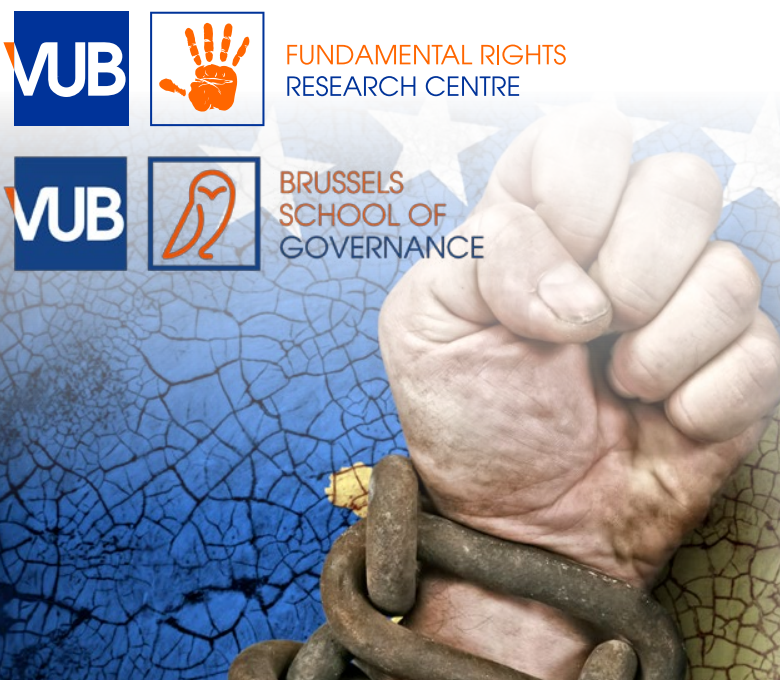

\section{Personal Response}

Is there a statute of limitations that will restrict the prosecution of crimes from 1998/1999, either in intemationallaw or in Servian/Kosovan law? If not, should there be?

II It is widely accepted under international law that there are no statute of limitations for the so-called core international crimes: genocide, crimes against humanity, war crimes and the crime of aggression. This is justifiable both because of the gravity of these crimes and because of the considerable historical, political and societal impact they engender. The collective, broader societal dimension of these crimes generates an interest to see them prosecuted, even if a long period has passed after the commission of the crimes. This does not mean that it is always and at all times opportune to initiate prosecutions for atrocity crimes committed decades of prosecuting very aged defendants, as happens in present-day Germany, where alleged crimes committed by former Nazi officials who are sometimes over hundred
years old are being investigated and prosecuted.

Is there any marked difference in the outlook of young Serbs and Kosovans (those too young to remember future, or have old battlelines continued to divide the

II For young Serbs and Kosovans in their twenties and thirties, the war continues to be a dividing issue. While they maybe not fully remember the violence itself, they surely felt the impact of the war on their daily lives. Because the even younger Serbs and Kosovans born after the war are for the most part still minors, it is difficult to gauge whether they hold markedly different outlooks compared to the older groader trend discernible, which tends to show that the youder rend discernible, which tends to show that the corruption over war-related issues and the dialogue between Serbia and Kosovo. 